\title{
Simulation of coal char gasification using $\mathrm{O}_{2} / \mathrm{CO}_{2}$
}

\author{
Haibin Li $\cdot$ Yu Yu $\cdot$ Minfang Han $\cdot$ Ze Lei
}

Received: 14 October 2013/Revised: 10 March 2014/Accepted: 13 March 2014/Published online: 12 September 2014

(C) The Author(s) 2014. This article is published with open access at Springerlink.com

\begin{abstract}
The authors proposed an integrated gasification fuel cell zero-emission system. The coal char gasification is discussed using high temperature and concentration of $\mathrm{CO}_{2}$ produced by solid oxide fuel cells and oxy-fuel combustion. The gasification is simulated by Aspen plus based on Gibbs free energy minimization method. Gasification model of pulverized coal char is computed and analyzed. Effects of gas flow rate, pressure, preheating temperature, heat losses on syngas composition, reaction temperature, lower heating value and carbon conversion are studied. Results and parameters are determined as following. The optimum $\mathrm{O}_{2}$ flow rate is $20 \mathrm{~kg} / \mathrm{h}$. The reaction temperature decreases from 1645 to $1329{ }^{\circ} \mathrm{C}$ when the $\mathrm{CO}_{2}$ flow rate increases from 0 to $5 \mathrm{~kg} / \mathrm{h}$, the $\mathrm{CO}_{2}$ flow rate should be operated reasonably; lower heating value reduces and reaction temperature increases as the pressure increases; compared to the $\mathrm{CO}_{2}$ preheating, $\mathrm{O}_{2}$ preheating has greater influence on reaction temperature and lower heating value.
\end{abstract}

Keywords Coal char · Gasification · Aspen plus

\section{Introduction}

In recent years, global demand for fossil energy has been growing rapidly with the economic and social development of the world. Long-term use of fossil energy has led to serious environmental problems. Especially the green house effect is getting worse because of $\mathrm{CO}_{2}$ emission, which has attracted worldwide concerns (Gleick et al. 2010; Mao 2010; Wei et al. 2011). Chinese government has proposed that by the year $2020, \mathrm{CO}_{2}$ emission of unit GDP could be reduced by $40 \%$ to $45 \%$ compared with the emission in 2005. As a result, $\mathrm{CO}_{2}$ emission reduction and development of low carbon science and technology have become the most urgent scientific issues to solve for the world (Xie H 2010; Xie et al. 2012).

Coal production in China was 3.66 billion tons in 2012, increased by $4 \%$ than in 2011. Coal utilization is the main

H. Li · Y. Yu · M. Han $(\bowtie) \cdot$ Z. Lei

School of Chemical and Environmental Engineering, China University of Mining and Technology, Beijing 100083, China e-mail: hanminfang@sina.com source of $\mathrm{CO}_{2}$ emission. The percentage of $\mathrm{CO}_{2}$ emission produced by coal utilization is as high as $70 \%$ (Huang 2012; Sun and Gao 2013). Clean and effective utilization of coal is the key to achieve sustainable development of energy for the world, especially for China. Coal gasification is the core technology in fuel cells, coal chemical synthesis, IGCC, and coal gasification-based poly-generation. It is the most efficient way to achieve clean and effective utilization of coal.

$\mathrm{CO}_{2}$ can be used as gasification agent to gasify coal char. Then high purity CO can be used for chemical synthesis and Solid Oxide Fuel Cells (SOFCs), which can realize clean and effective utilization of coal (Peng and Han 2009).

Coal gasification in $\mathrm{CO}_{2}$ rich gas atmosphere is recognized as one of the most promising technology for controlling $\mathrm{CO}_{2}$ emission in pulverized coal-fired power plants. This technology has been reviewed (Antonio and Mara 2004). Large amount of syngas, mainly CO, can be produced by this technology. Syngas production from coal gasification under $\mathrm{O}_{2} / \mathrm{CO}_{2}$ atmosphere has been simulated using CFD software Fluent. A 3D geometry simulation 
model for gasification was established. The results show that the gas temperature decreases and the gross heating value of syngas increases with the increasing of $\mathrm{CO}_{2}$ concentration; besides, effect of particle size on coal gasification is significant (Alam et al. 2012). Gasification of aquatic biomass under $\mathrm{O}_{2} / \mathrm{CO}_{2}$ atmosphere has been carried out. Effects of $\mathrm{O}_{2}, \mathrm{CO}_{2}$ concentrations, feeding rate and $\left[\mathrm{H}_{2} \mathrm{O}\right] /[\mathrm{C}]$ ratio on $\mathrm{O}_{2} / \mathrm{CO}_{2}$ gasification behavior have been reported (Toshiaki et al. 2009; Toshiaki et al. 2013).

The syngas produced by coal gasification can be used for SOFCs. Then high temperature and concentration of $\mathrm{CO}_{2}$ is produced after electrochemical reaction. The $\mathrm{CO}_{2}$ could be used for gasification of char. For this closed cycle system, vast heat of exhaust could be used efficiently and energy needed in the gasification could be reduced. Also the system can realize $\mathrm{CO}_{2}$ emission reduction and even zero emission. The specific principle is shown in Fig. $1 . \mathrm{O}_{2}$ can be separated from air by oxygen transportation Membrane (OTM), which is prepared by perovskite powders

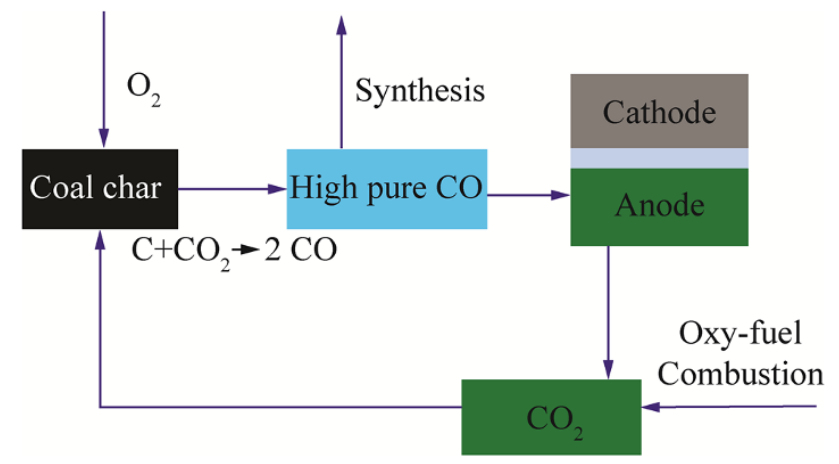

Fig. 1 Closed cycle system of $\mathrm{CO}_{2}$ gasification of coal char and operated at high temperature from 800 to $1000{ }^{\circ} \mathrm{C}$. Then high temperature $\mathrm{O}_{2}$ is produced.

The process flowsheet simulation program Aspen plus is used in this paper. The simulation is based on entrainedflow gasifier. The physical property databases and unit module in Aspen plus have also been used in the simulation model. Coal char gasification model under $\mathrm{O}_{2} / \mathrm{CO}_{2}$ has been established, which can provide theory bases for the determination of process conditions.

\section{Establishment of simulation model}

As shown in Fig. 2, the simulation model consists of three unit modules, five material streams and two heat streams. They are the unit module of RYIELD, RGIBBS, SSPLIT; material streams of NATCOKE (coal char), $\mathrm{CO}_{2}, \mathrm{O}_{2}$, SYNGAS and ash; heat streams of QLOSE (heat loss of the gasifier) and QDECOMP (Heat of char cracking). The reaction blocks used are the RYIELD, RGIBBS and SSPLIT. Nonconventional material of coal char can crack to single element molecule in the RYIELD reactor and the cracking heat can be led into the RGIBBS reactor.

\section{Results and discussion}

\subsection{Effect of $\mathrm{O}_{2}$ flow rate on the gasification}

The computation in the RGIBBS reactor is based on Gibbs free energy minimization method. SSPLIT module is used to simulate the separation of syngas and ash. The model is established under the assumptions that the gasifier runs

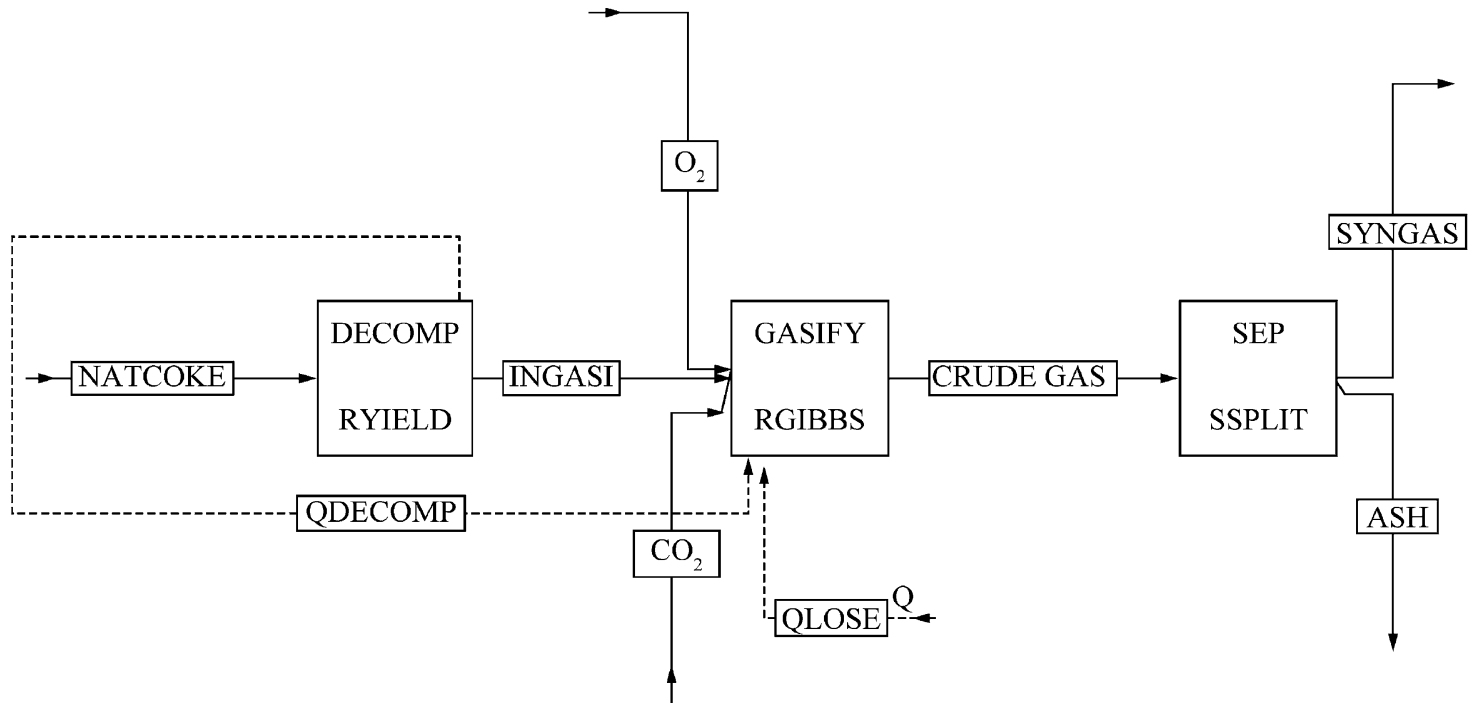

Fig. 2 Diagram of Aspen plus model 
Table 1 Properties of coal char

\begin{tabular}{|c|c|c|c|c|c|c|c|c|c|c|c|c|}
\hline \multicolumn{4}{|c|}{ Proximate analysis $(\%)$} & \multicolumn{5}{|c|}{ Ultimate analysis (\%) (d) } & \multicolumn{3}{|c|}{ Sulfur analysis/ \% (d) } & \multirow[t]{2}{*}{ Heating value $(\mathrm{MJ} / \mathrm{kg})$} \\
\hline $\mathrm{M}_{\mathrm{ad}}$ & $A_{d}$ & $\mathrm{~V}_{\mathrm{d}}$ & $\mathrm{FC}_{\mathrm{d}}$ & $\mathrm{C}_{\mathrm{d}}$ & $\mathrm{H}_{\mathrm{d}}$ & $\mathrm{O}_{\mathrm{d}}$ & $\mathrm{N}_{\mathrm{d}}$ & $\mathrm{S}_{\mathrm{d}}$ & $\mathrm{S}_{\mathrm{p}}$ & $\mathrm{S}_{\mathrm{s}}$ & $\mathrm{S}_{\mathrm{o}}$ & \\
\hline 0.81 & 16.28 & 9.12 & 74.6 & 77.96 & 1.66 & 2.69 & 0.92 & 0.48 & 0.2 & 0.12 & 0.16 & 26.81 \\
\hline
\end{tabular}

(ad-air dried base, $d$-dried base)

stably, no operating parameters change, the gasification agent and coal char particle can mix completely instantly, the elements hydrogen, oxygen, nitrogen and sulfur convert to gas phase totally except element carbon. There is no pressure drop in the gasifier, ash in the coal char is inert material that does not take part in gasification reaction, temperature distribution in coal particle is uniform, all the gas-state reactions are fast and attain equilibrium (Wang et al. 2004; Zhou et al. 2010).

Coal char used in this paper is from Xuzhou, China (Lin and Zhao 2012). The proximate analysis, ultimate analysis and sulfur analysis are shown in Table $1 . \mathrm{O}_{2}$ and $\mathrm{CO}_{2}$ are chosen as gasification agents. The handling capacity of coal char is $21.59 \mathrm{~kg} / \mathrm{h}$ (The mass flow rates are set according to simulation requirement). Gasification pressure is $3 \mathrm{MPa}$ when it keeps steady. Mass ratio of $\mathrm{O}_{2}, \mathrm{CO}_{2}$ to coal char is the key factor to the quality of syngas.

Other parameters keep steadily. The coal char and $\mathrm{CO}_{2}$ mass flow rate are 21.59 and $2.16 \mathrm{~kg} / \mathrm{h}$ respectively. The relationships among syngas composition, reaction temperature, lower heating value of syngas and $\mathrm{O}_{2}$ content are shown in Fig. 3. The reaction temperature increases rapidly with the rising of $\mathrm{O}_{2}$ content because of the increased combustion reaction. At the start of gasification there is not enough $\mathrm{O}_{2}$, so imperfect combustion of char occupies a predominant position. As a result, molar ratio of $\mathrm{CO}$ increases gradually at first. Then the molar fraction of $\mathrm{CO}$ decreases because the complete combustion reaction increases as a result of more $\mathrm{O}_{2}$ being injected into the gasifier. Combustion reactions of $\mathrm{H}_{2}$ and $\mathrm{CO}$ increase with the rising of $\mathrm{O}_{2}$ content, which leads to higher $\mathrm{H}_{2} \mathrm{O}$ and $\mathrm{CO}_{2}$ content.

As shown in Fig. 3 the concentration of $\mathrm{CO}$ increases with the increasing of $\mathrm{O}_{2}$ flow rate, and then decreases. Although the concentration of $\mathrm{H}_{2}$ decreases gradually, it is much lower than CO's. As a result, the concentration of $\mathrm{CO}$ is the leading factor, which promotes lower heating value and the lower heating value of syngas increasing to the maximum value and then decreasing with increasing of $\mathrm{O}_{2}$ mass flow rate.

\subsection{Effect of $\mathrm{CO}_{2}$ flow rate on the gasification}

As illustrated in Fig. 4 the reaction temperature decreases gradually with the increasing of $\mathrm{CO}_{2}$ flow rate when the coal char and $\mathrm{O}_{2}$ mass flow rates are 21.59 and $17.57 \mathrm{~kg} / \mathrm{h}$
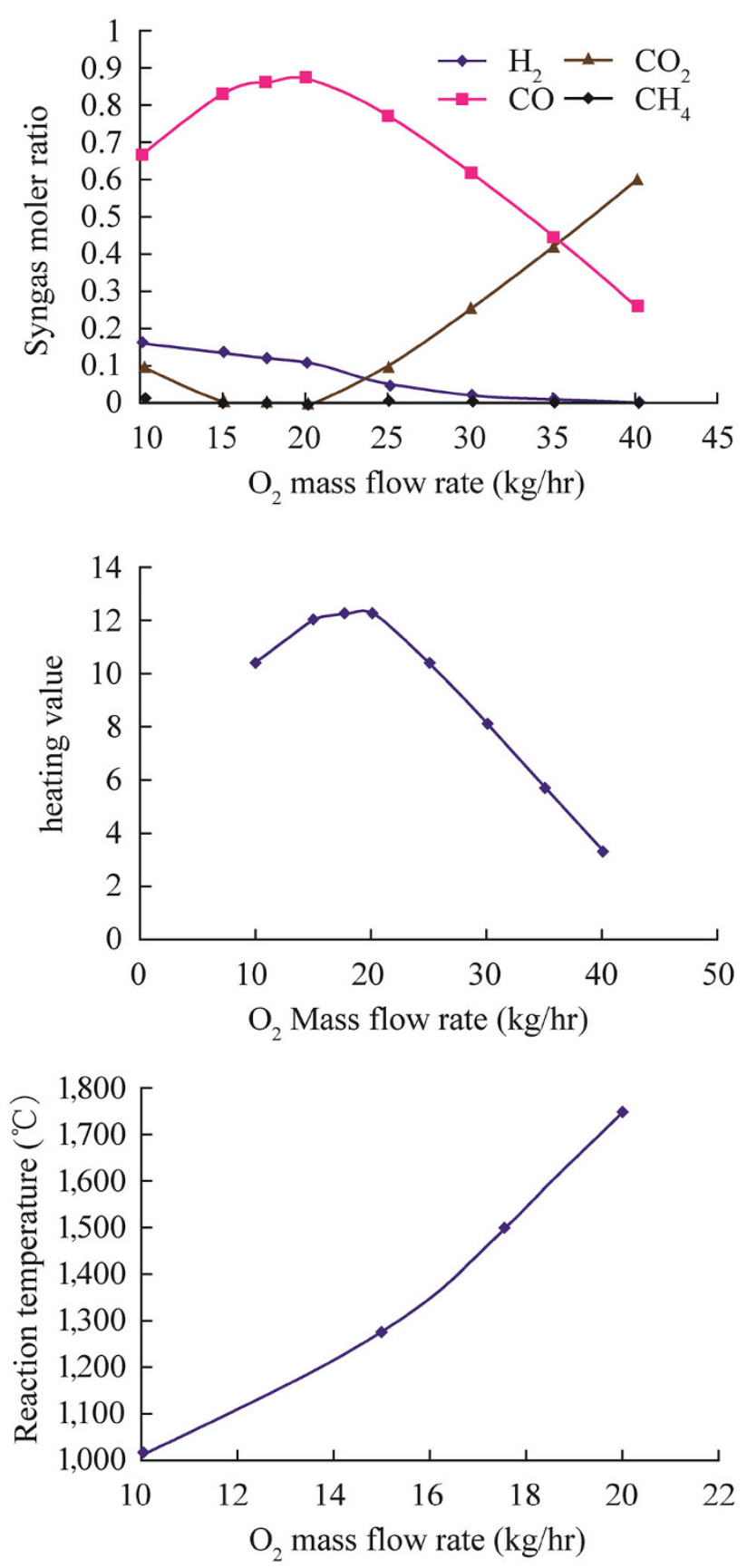

Fig. 3 Effects of $\mathrm{O}_{2}$ content on syngas composition, reaction temperature and lower heating value of syngas $\left(\mathrm{MJ} / \mathrm{m}^{3}\right)$. Notes The reaction temperature is much higher than $1,700{ }^{\circ} \mathrm{C}$ when the $\mathrm{O}_{2}$ mass flow rates are larger than $20 \mathrm{~kg} / \mathrm{h}$, which does not accord with the reality. As a result, the abscissa value in the last figure of Fig. 3 is no more than $20 \mathrm{~kg} / \mathrm{h}$ 

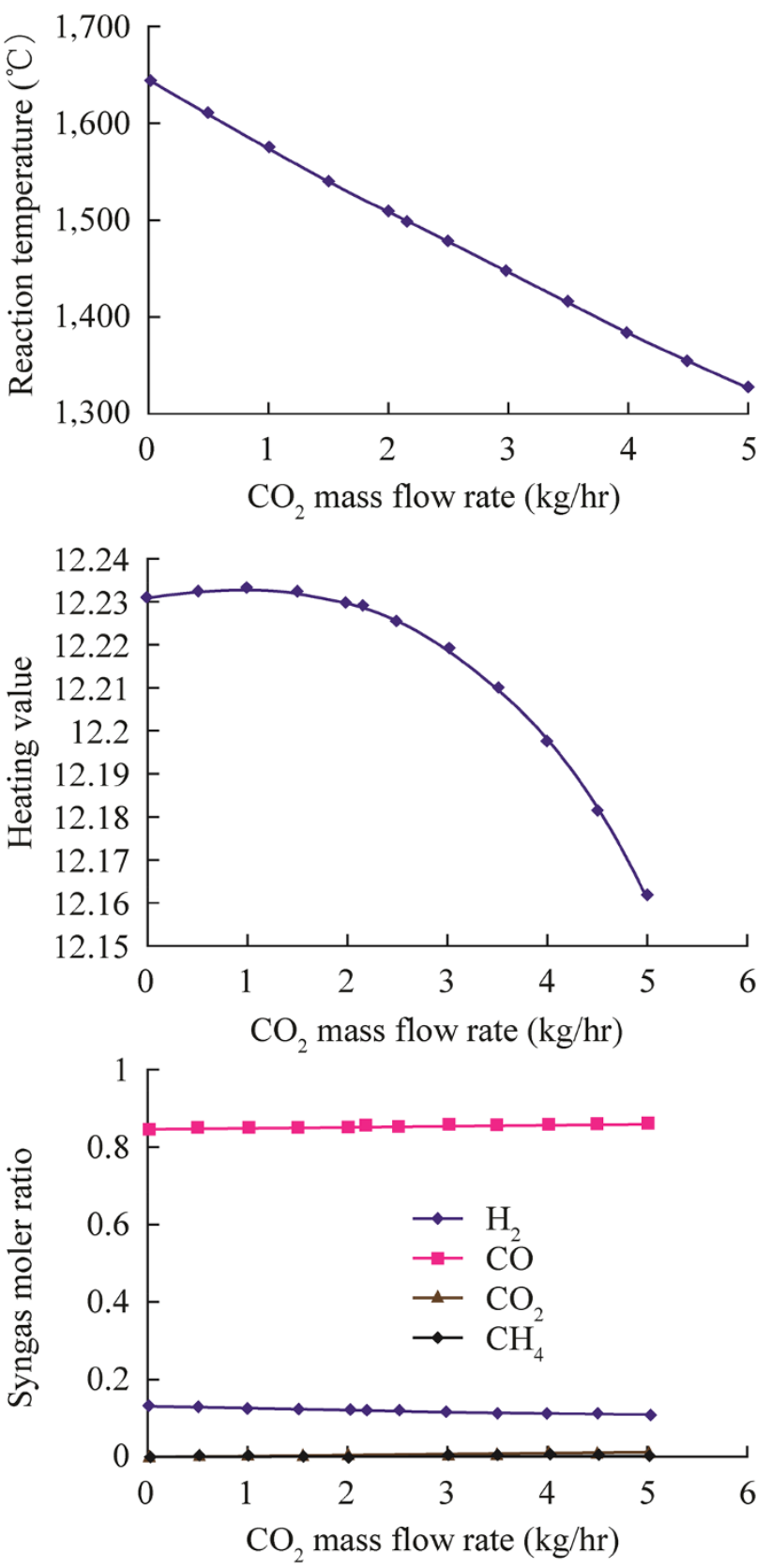

Fig. 4 Effect of $\mathrm{CO}_{2}$ content on syngas composition, reaction temperature and lower heating value of syngas $\left(\mathrm{MJ} / \mathrm{m}^{3}\right)$

respectively. It decreases from $1645{ }^{\circ} \mathrm{C}$ to $1329{ }^{\circ} \mathrm{C}$ when $\mathrm{CO}_{2}$ flow rate increases from 0 to $5 \mathrm{~kg} / \mathrm{h}$. Reaction temperature decreasing is caused by several factors listed below. First, diffusion rate of $\mathrm{O}_{2}$ in the $\mathrm{CO}_{2}$ atmosphere is slower with the increasing of $\mathrm{CO}_{2}$ flow rate, which leads to slower combustion reaction. Second, the larger heat capacity of $\mathrm{CO}_{2}$, increasing of $\mathrm{CO}_{2}$ flow rate and keeping $\mathrm{O}_{2}$ flow rate steady, leads to lower reaction temperature. Third, the Boudouard reaction rate is enhanced with the increasing of $\mathrm{CO}_{2}$ flow rate and more heat is consumed, which leads to lower reaction temperature.
Reaction temperature decreasing is not favorable to Boudouard reaction. However, the increasing of $\mathrm{CO}_{2}$ concentration promotes Boudouard reaction and its effect on Boudouard reaction is more dominant than the temperature. As a result, the molar ratio of $\mathrm{CO}$ increases with the rising of $\mathrm{CO}_{2}$ flow rate. Reaction of coal char with $\mathrm{H}_{2} \mathrm{O}$ is endothermic. Temperature decreasing is not favorable to the reaction. Temperature decreasing is good for water gas shift reaction and the production of $\mathrm{CO}_{2}$ and $\mathrm{H}_{2}$, but the concentrations of $\mathrm{CO}_{2}$ and $\mathrm{H}_{2}$ are very low. Therefore, the reaction of coal char with $\mathrm{H}_{2} \mathrm{O}$ is more dominant in the production of $\mathrm{H}_{2}$. As shown in Fig. 4, the concentration of $\mathrm{H}_{2}$ decreases with the increasing of $\mathrm{CO}_{2}$.

The reverse water gas shift reaction increases as a result of increasing of $\mathrm{CO}_{2}$ and partly $\mathrm{H}_{2}$ converts to $\mathrm{H}_{2} \mathrm{O}$. As a result, the lower heating value of syngas decreases slightly with the increasing of $\mathrm{CO}_{2}$ mass flow rate as shown in the Fig. 4.

\subsection{Effect of pressure on the gasification}

The relationship of the pressure with gasification is shown in Fig. 5 when the coal char, $\mathrm{O}_{2}$ and $\mathrm{CO}_{2}$ mass flow rate are $21.59,17.57$ and $2.16 \mathrm{~kg} / \mathrm{h}$ respectively. The reverse Boudouard reaction rate increases with the rising of pressure, which leads to slightly decreasing of $\mathrm{CO}$ molar ratio and increasing of heat and $\mathrm{CO}_{2}$ content. The reaction temperature is high enough and the effect of pressure is not remarkable, but pressurizing can increase syngas production per unit time and production capacity. $\mathrm{CO}_{2}$ content increasing is favorable to the reverse water gas shift reaction and the molar ratio of $\mathrm{H}_{2}$ decreases. As a result, the lower heating value decreases slightly.

\subsection{Effect of preheating temperature on the gasification}

Effect of preheating temperature on the gasification with coal char, $\mathrm{O}_{2}$ and $\mathrm{CO}_{2}$ mass flow rates are 21.59, 17.57 and $2.16 \mathrm{~kg} / \mathrm{h}$ is shown in Fig. 6. The preheating of $\mathrm{O}_{2}$ and $\mathrm{CO}_{2}$ can increase the reaction temperature and the lower heating value, but the effect of $\mathrm{CO}_{2}$ preheating on reaction temperature and lower heating value is weaker than the $\mathrm{O}_{2}$ preheating. The reaction temperature and the heating value increase by only $25{ }^{\circ} \mathrm{C}$ and $0.0063 \mathrm{MJ} / \mathrm{M}^{3}$ respectively, when the preheating temperature of $\mathrm{CO}_{2}$ increases from 300 to $1000{ }^{\circ} \mathrm{C}$. However, the heat capacity of $\mathrm{CO}_{2}$ is so high that it is unnecessary for high preheating temperature.

\subsection{Effect of reaction temperature on the gasification}

To obtain the effect of temperature on gasification, heat loss of gasifier is introduced in the gasification. The gasifier 

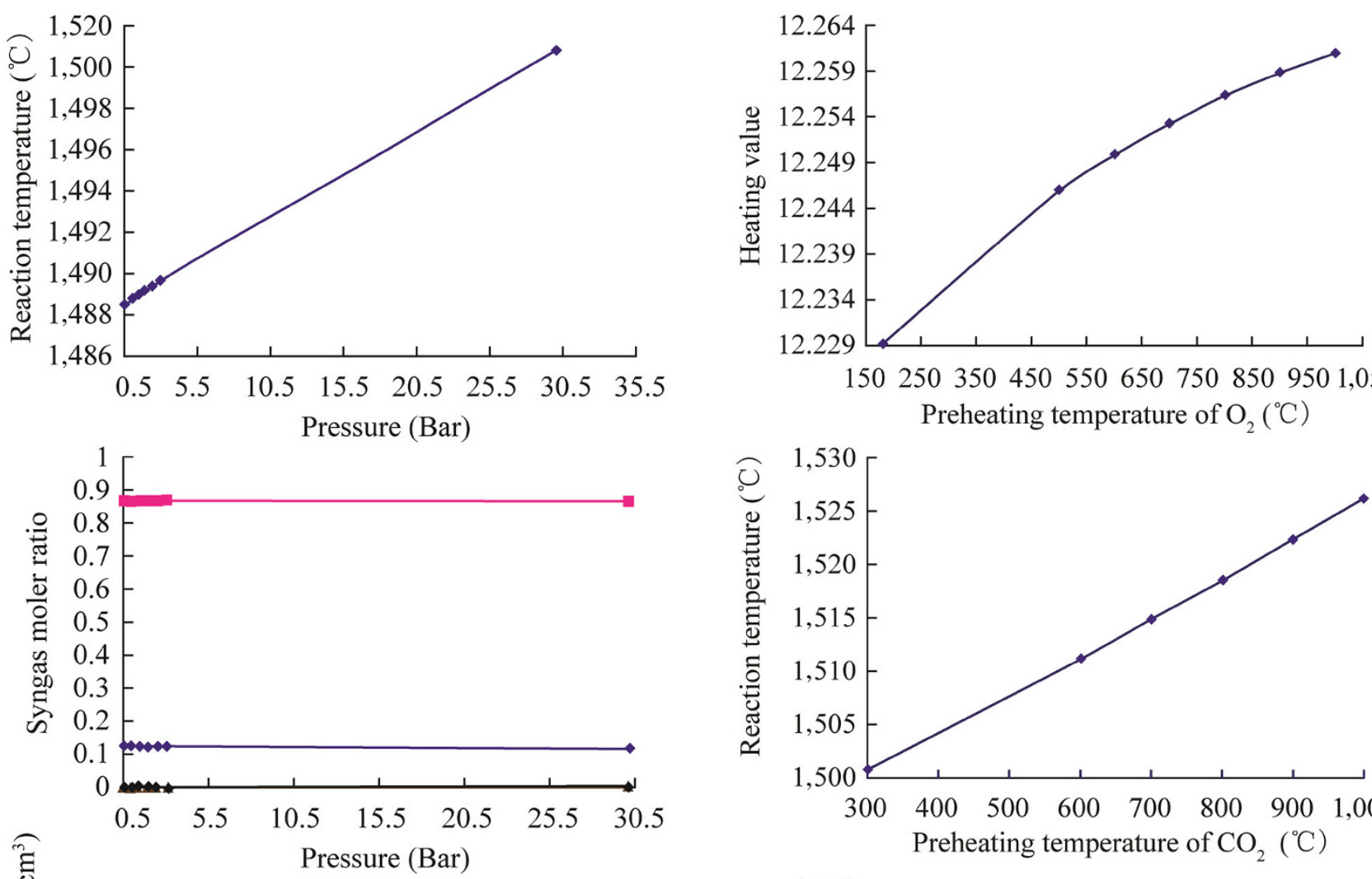

1502503504505506507508509501,050

Preheating temperature of $\mathrm{O}_{2}\left({ }^{\circ} \mathrm{C}\right)$
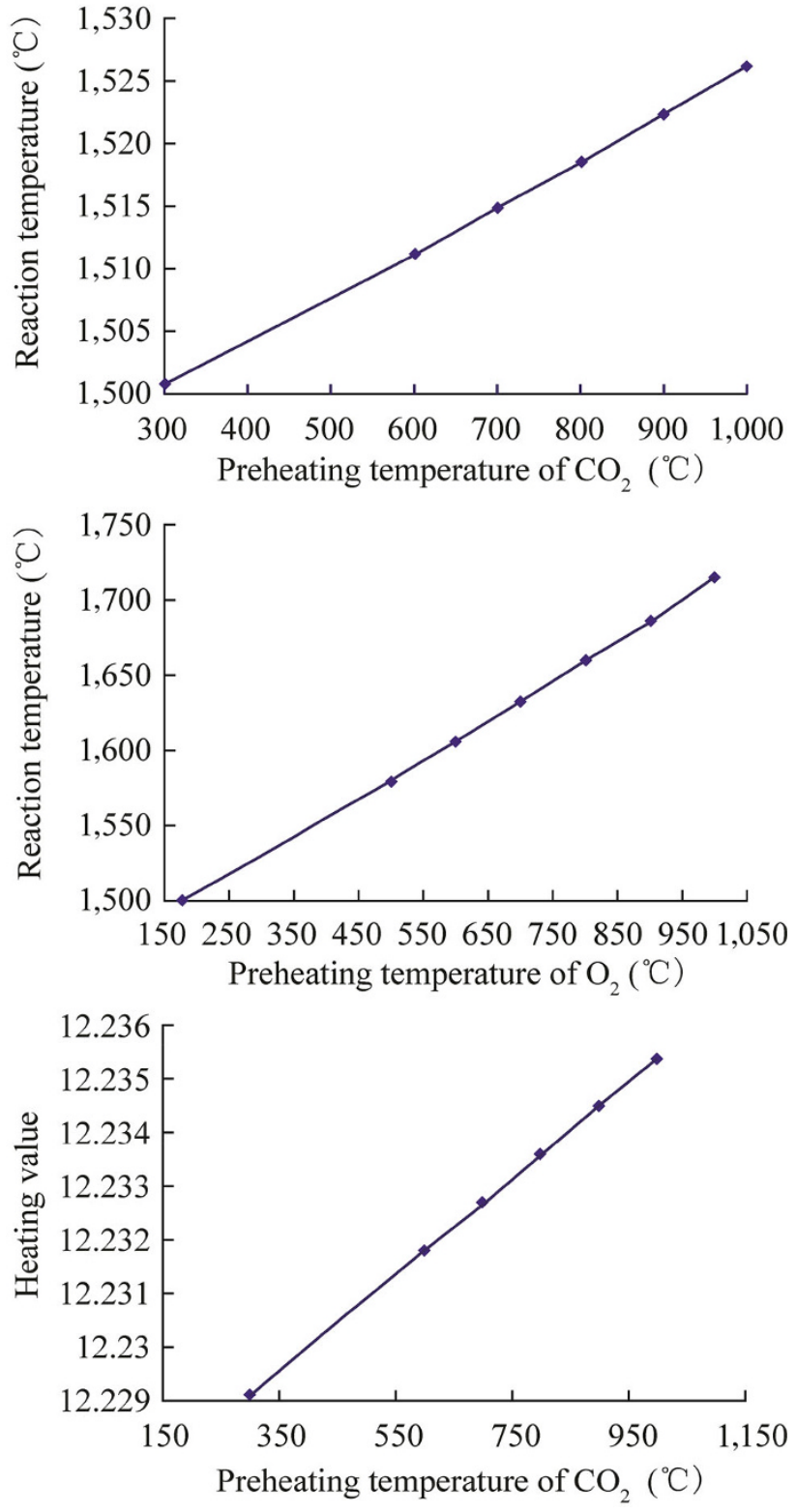

Fig. 5 Effect of pressure on syngas composition, reaction temperature and lower heating value of syngas $\left(\mathrm{MJ} / \mathrm{m}^{3}\right)$

heat loss is the ratio of heat loss of the gasifier with heating value of coal. As coal char, $\mathrm{O}_{2}$ and $\mathrm{CO}_{2}$ mass flow rates are $21.59,17.57$ and $2.16 \mathrm{~kg} / \mathrm{h}$ separately, the relationships between syngas composition, temperature, lower heating value and gasifier heat loss are illustrated in Fig. 7. Reaction temperature decreases as the heat loss increases from $0 \%$ to $2 \%$, which leads to slower Boudouard reaction rate and lower molar fraction of $\mathrm{CO}$. The $\mathrm{H}_{2}$ content decreases because of the decreasing temperature and the reaction rate of char with $\mathrm{H}_{2} \mathrm{O}$.

Fig. 6 Effect of preheating temperature on reaction temperature and lower heating value of syngas $\left(\mathrm{MJ} / \mathrm{m}^{3}\right)$ Notes $\mathrm{O}_{2}$ preheating temperature is much high because the $\mathrm{O}_{2}$ is separated by OTM which is operated about 800 to $1000{ }^{\circ} \mathrm{C}$ 

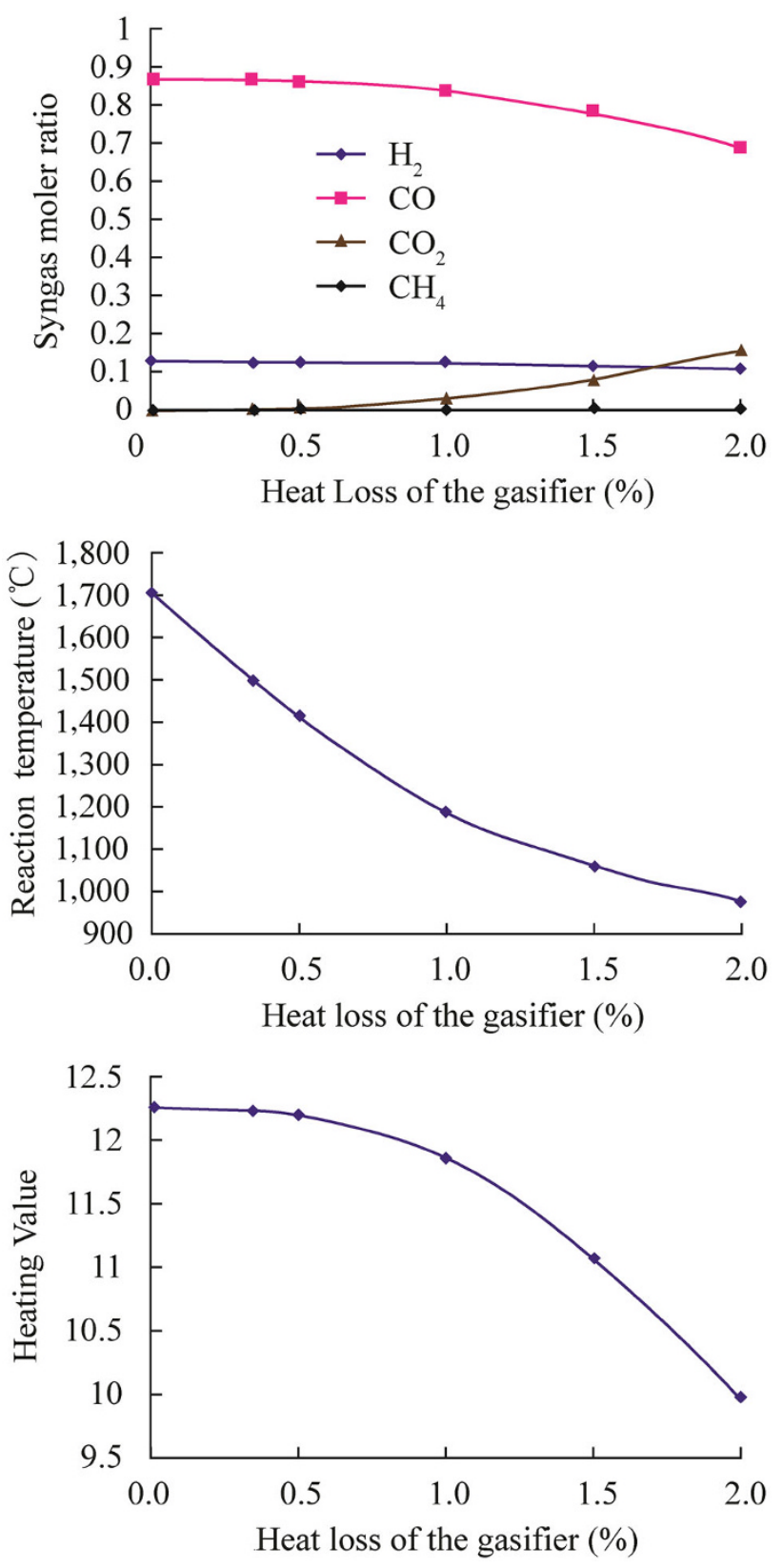

Fig. 7 Effect of heat losses of gasifier on syngas composition, reaction temperature and lower heating value of syngas $\left(\mathrm{MJ} / \mathrm{m}^{3}\right)$

\subsection{Effects of different factors on the carbon conversion}

Effects of $\mathrm{O}_{2}$ and $\mathrm{CO}_{2}$ mass flow rates, pressure, preheating temperature and heat loss on the carbon conversion were simulated. The results are shown in Table 2.

Carbon conversion increases with increasing of $\mathrm{O}_{2}$ and $\mathrm{CO}_{2}$ mass flow rates. Carbon combustion reactions are enhanced with the increasing of $\mathrm{O}_{2}$ mass flow rates so carbon conversion increases greatly. We can get that the optimum $\mathrm{O}_{2}$ mass flow rate is $20 \mathrm{~kg} / \mathrm{h}$ for syngas heating value in Fig. 3. Increasing of $\mathrm{CO}_{2}$ mass flow rates is good for Boudouard reaction and carbon conversion. Pressure, preheating and gasifier heat loss have also some effects on carbon conversion, but they are not apparent.

\section{Conclusions}

The coal char gasification using $\mathrm{O}_{2} / \mathrm{CO}_{2}$ based on IGFC was proposed. The thermodynamic analysis of the gasification under $\mathrm{O}_{2} / \mathrm{CO}_{2}$ atmosphere was studied using Aspen plus simulation method. The results are concluded as following.

(1) The molar ratio of CO increased gradually when the $\mathrm{O}_{2}$ flow rate is lower than $20 \mathrm{~kg} / \mathrm{h}$. Then the molar fraction of $\mathrm{CO}$ decreases. $\mathrm{H}_{2}$ molar ratio decreases gradually with the increasing of $\mathrm{O}_{2}$ mass flow rate. The optimum lower heating value is obtained when the $\mathrm{O}_{2}$ flow rate is $20 \mathrm{~kg} / \mathrm{h}$.

(2) The Mass flow rates of $\mathrm{CO}_{2}$ has a significant effect on reaction temperature. The reaction temperature decreases from 1645 to $1329{ }^{\circ} \mathrm{C}$ when $\mathrm{CO}_{2}$ flow rates increases from 0 to $5 \mathrm{~kg} / \mathrm{h}$ because of the slower diffusion of $\mathrm{O}_{2}$ in $\mathrm{CO}_{2}$ atmosphere, larger heat

Table 2 Effect of different factors on carbon conversion

\begin{tabular}{lllllll}
\hline $\mathrm{O}_{2}$ mass flow rates $(\mathrm{kg} / \mathrm{h})$ & 10 & 15 & 17.5 & 20 & & \\
Carbon conversion & 0.4343 & 0.7272 & 0.8537 & 0.9657 & 5 & 4 \\
$\mathrm{CO}_{2}$ mass flow rates $(\mathrm{kg} / \mathrm{h})$ & 0 & 0.5 & 1.5 & 2.16 & 3 & 0.8911 \\
Carbon conversion & 0.8208 & 0.8286 & 0.8439 & 0.8538 & 0.8657 & 0.8791 \\
Pressure $($ bar) & 1 & 2 & 3 & 4 & 5 & 30 \\
Carbon conversion & 0.8581 & 0.8579 & 0.8578 & 0.8576 & 0.8574 & 0.8537 \\
$\mathrm{O}_{2}$ preheating $\left({ }^{\circ} \mathrm{C}\right)$ & 100 & 200 & 400 & 600 & 700 & 800 \\
Carbon conversion & 0.8532 & 0.8538 & 0.8547 & 0.8555 & 0.8558 & 0.856 \\
$\mathrm{CO}_{2}$ preheating $\left({ }^{\circ} \mathrm{C}\right)$ & 300 & 600 & 700 & 800 & 900 & 0.800 \\
Carbon conversion & 0.8537 & 0.8539 & 0.854 & 0.8541 & 0.8541 & 0.8542 \\
Heat loss of gasifier $(\%)$ & 2.5 & 2 & 1.5 & 0.5 & 0 & 0.8563 \\
Carbon conversion & 0.8537 & 0.8545 & 0.8551 & 0.8561 & 0.8564 & \\
\hline
\end{tabular}


capacity of $\mathrm{CO}_{2}$ and promoting of Boudouard reaction. The syngas lower heating value decreases gradually with the increasing of $\mathrm{CO}_{2}$ mass flow rates.

(3) The heating value is lower with the raising of pressure, but pressurize is favorable to reaction temperature. The molar ratios of $\mathrm{CO}$ and $\mathrm{H}_{2}$ decreased slightly even under high pressure because of the high reaction temperature.

(4) Preheating of $\mathrm{O}_{2}$ and $\mathrm{CO}_{2}$ can both enhance reaction temperature and syngas heating value, but effect of $\mathrm{CO}_{2}$ preheating is weaker than $\mathrm{O}_{2}$ preheating.

(5) The carbon conversion increases with the increasing of $\mathrm{O}_{2}, \mathrm{CO}_{2}$ flow rates and $\mathrm{O}_{2}, \mathrm{CO}_{2}$ preheating temperature. Pressure is not favorable to the carbon conversion because it could inhibit the Boudouard reaction. The gasifier heat loss can reduce reaction temperature and then the carbon conversion decreases.

Acknowledgments We are grateful to the National Basic Research Program of China (No. 2012CB215404, 2012CB215406), the National Natural Science Foundation of China (No. 51261120378) for financial support of this work.

Open Access This article is distributed under the terms of the Creative Commons Attribution License which permits any use, distribution, and reproduction in any medium, provided the original author(s) and the source are credited.

\section{References}

Alam MS, Wijayanta AT, Nakaso K, Fukai J (2012) Numerical investigation of syngas production from coal gasification under various $\mathrm{CO}_{2} / \mathrm{O}_{2}$ mixtures. Can J Comput Math Nat Sci Eng Med 3(4):88-97

Antonio C, Mara DJ (2004) Mild combustion. Prog Energy Combust Sci 30(4):329-366

Gleick PH, Adams RM, Amasino RM et al (2010) Climate change and the integrity of science. Science 328:689-690

Huang J (2012) Coal list and study on emission reduction policy. Doctor's Thesis, University of Fudan

Lin LS, Zhao CS (2012) Study of the simulation of natural coke- $\mathrm{H}_{2} \mathrm{O}$ gasification reaction by using the software Aspen plus. J Eng Therm Energy Power 27(3):355-360

Mao ZQ (2010) Discussing about $\mathrm{CO}_{2}$ emission and $\mathrm{H}_{2}$ energy. Mod Phys 22(5):41-45

Peng SP, Han MF (2009) Development of coal/carbon based solid oxide fuel cell. Chin J Nat 31(4):187-192

Sun CS, Gao F (2013) Review of development of China's coal industry in 2012 and prediction of its development trend in 2013. China Coal 39(3):10-16

Toshiaki H, Hiroto S, Kinya S, Yusuke E (2009) Syngas production by woody biomass gasification with a $\mathrm{CO}_{2} / \mathrm{O}_{2}$ mixture. J Jpn Inst Energy 88:862-868

Toshiaki $\mathrm{H}$, Shou $\mathrm{H}$, Yusuke E (2013) Syngas production by $\mathrm{CO}_{2} / \mathrm{O}_{2}$ gasification of a aquatic biomass. Fuel Process Technol 116:9-15

Wang Y, Dai ZH, Yu GS, Yu ZH (2004) Simulation of entrained-flow bed coal gasifier by the method of Gibbs free energy minimization. Coal Convers 27(4):27-33

Wei W, Sun YH, Wen X, Sun NN (2011) Opportunities and challenges of carbon dioxide utilization as a resource. Chem Ind Eng Prog 30(1):216-224

Xie HP (2010) CO2 storage and climate change. Science and Technology Review 28(18)

Xie HP, Xie LZ, Wang YF, Zhu JY, Liang B, Ju Y (2012) CCU: a more feasible and economic strategy than CCS for reducing $\mathrm{CO}_{2}$ emissions. J Sichuan Univ 44(4):1-5

Zhou JH, Chen XL, Guo Q, Wang YZ (2010) Process simulation of biomass and coal entrained flow co-gasification based on Aspen plus. Acta Energiae Solaris Sinica 31(9):1112-1116 